\title{
Efficacy and Safety of Paromomycin for Visceral Leishmaniasis: A Systematic Review
}

\author{
Pashupati Pokharel $\mathbb{D}^{1},{ }^{1}$ Rakesh Ghimire, ${ }^{2}$ and Pratik Lamichhane $\mathbb{D D}^{1}$ \\ ${ }^{1}$ Maharajgunj Medical Campus, Institute of Medicine, Kathmandu, Nepal \\ ${ }^{2}$ Department of Clinical Pharmacology, Maharajgunj Medical Campus, Institute of Medicine, Kathmandu, Nepal
}

Correspondence should be addressed to Pashupati Pokharel; pashupatipokharel@iom.edu.np

Received 28 May 2021; Revised 11 July 2021; Accepted 17 July 2021; Published 26 July 2021

Academic Editor: Alemayehu Toma

Copyright ( $) 2021$ Pashupati Pokharel et al. This is an open access article distributed under the Creative Commons Attribution License, which permits unrestricted use, distribution, and reproduction in any medium, provided the original work is properly cited.

\begin{abstract}
Visceral leishmaniasis, also known as kala-azar is one of the most commonly neglected tropical diseases affecting a large number of rural and resource-limited people in South Asia, Africa, and South America. Paromomycin, an aminoglycoside drug, is frequently used for the treatment of visceral leishmaniasis. Despite limited therapies for visceral leishmaniasis and emerging drug resistance, a proper review on the action of paromomycin for kala-azar is lacking. This systematic review aims to look for the efficacy and safety aspects of paromomycin for the treatment of visceral leishmaniasis.
\end{abstract}

\section{Introduction}

Visceral leishmaniasis (VL) commonly known as kala-azar is characterized by fever, hepatosplenomegaly, and pancytopenia [1]. The disease is primarily caused by protozoan parasite of species Leishmania donovani and Leishmania infantum, transmitted to humans by the bite of female sand fly, Phlebotomine. Leishmaniasis is considered one of the most neglected diseases due to its strong association with poverty and limited resources invested in new tools and technologies for the diagnosis, treatment, and control $[2,3]$. The recent 2017 Global Burden of Disease Study estimated that Neglected Tropical Diseases (NTDs) were responsible for 62 million Disability-Adjusted Life Years (DALYs), with 774,000 DALYs from leishmaniasis [4]. In 2015, VL contributed $97 \%$ of the total DALYs for the leishmaniases [5], ranking it as the second leading cause of parasitic deaths after malaria [6].

Visceral leishmaniasis is endemic in 79 countries, mainly in the regions of the Indian subcontinent, East Africa, and South America. According to the World Health Organization (WHO), an estimated 50,000 to 90,000 new cases of VL occur worldwide annually [7]. As per the WHO database till January 2021, more than $90 \%$ of global VL cases were reported from eight countries: Brazil, Eritrea, Ethiopia, India, Kenya, Somalia, South Sudan, and Sudan [8]. Frequent epidemics of VL occur in East Africa and South Asia. In South America, 97\% of the VL cases concentrated in Brazil. However, there has been a geographic expansion of the disease into neighboring countries leading to rise in imported cases in Argentina, Colombia, and Uruguay [9].

Treatment options for VL are limited to few groups of drugs. In the past decades, pentavalent antimony compounds were the first-line therapy for VL, but due to their innate toxicity $[10,11]$ and frequent parasitic resistance [12], newer drugs such as amphotericin $B$, miltefosine, and paromomycin got approval for the treatment of VL. In cases of resistance to antimony compounds, amphotericin $\mathrm{B}$ $(\mathrm{AmB})$ is preferred for treatment. Amphotericin B is an expensive drug requiring hospitalization and close monitoring for weeks. The liposomal form of amphotericin B has a shorter course of treatment but is even more expensive with nearly thirty times the cost of conventional therapy for VL $[13,14]$. Miltefosine despite being oral therapy for VL is said to have potential teratogenic effects and frequent gastrointestinal side effects [15].

Paromomycin (PM) also known as monomycin or aminosidine is an aminoglycoside group of broad-spectrum 
antibiotics [16] with activity against Leishmania. The mechanism of PM against Leishmania is not completely understood yet. However, it is proposed that PM causes inhibition of translocation and recycling of ribosome subunits as well as modification in mitochondrial membrane potential leading to protein synthesis inhibition in Leishmania parasite [17]. This mechanism of action of PM against Leishmania is shown in Figure 1.

Especially, the intramuscular paromomycin at various doses is used for the treatment of VL. Due to the increasing importance of paromomycin as a therapeutic option for the treatment of VL for the last three decades and increasing trends of drug-resistant parasite, we aimed to conduct a systematic review to look for the efficacy of injectable paromomycin and to review its safety aspects.

\section{Methods}

2.1. Literature Search Strategy. A systematic literature search of databases such as PubMed and Google Scholar was conducted to identify all the relevant published articles from 1990 till April 10 2021. PubMed search was conducted using MeSH terms and keywords "Paromomycin," "Monomycin," "Aminosidine," "Visceral Leishmaniasis," "Kala azar," and "Black Fever" using suitable Boolean operators. Similarly, Google Scholar search was conducted using advanced search with similar keywords and suitable combinations. Authors of some studies were contacted via e-mail and ResearchGate for retrieval of full texts and clarification of doubts wherever required.

2.2. Study Selection. Literature search was performed according to the inclusion criteria. After reading all abstracts, key articles were identified by consensus. Full articles were obtained for all studies meeting the inclusion criteria for further assessment. Bibliographies of selected articles were also searched to identify relevant studies. The final list of included studies had the concurrence of all authors.

\subsection{Eligibility Criteria}

2.3.1. Inclusion Criteria. All articles published in English language between 1990 and 2021 in any setting with an aim of finding the efficacy and safety issues of injectable paromomycin for visceral leishmaniasis regardless of the Leishmania species whether L. donovani or L. infantum.

\subsubsection{Exclusion Criteria}

Studies aimed at finding efficacy of combination of paromomycin with any other drug used for treatment of VL.

Efficacy and safety studies of paromomycin in animals.

Paromomycin studies on VL considering other than efficacy and safety issues.
Case reports, review articles, conference papers, letter to the editor, and articles published in languages other than in English.

Full texts not accessible/irretrievable.

The systematic review was guided by the Preferred Reporting Items for Systematic Reviews and Meta Analyses (PRISMA) guidelines. The PRISMA diagram detailing the selection process is shown in Figure 2.

2.4. Data Collection and Data Items. Studies obtained from the electronic databases, supplementary sources, and manual searching were exported to EndNote reference software version 20 (Thomson Reuters, Stamford, CT, USA) in the compatible formats. Duplicate articles were screened first by EndNote and then manually. Duplicates were then recorded and removed. For multiple publications of the same data in more than one journal, the most inclusive, comprehensive studies, with larger sample size, and the most recent ones were considered.

The data items extracted from each study included author, journal and year of publication, country/place of study, study design, study population, age group, inclusion and exclusion criteria, dose and duration of paromomycin, outcome of treatment (efficacy), and adverse effects (safety issues).

\section{Results}

3.1. Study Selection. The initial electronic search identified 111 articles. After adjustment of duplicates, 102 articles remained. Of these, 93 articles were excluded after reading their titles and abstracts as they did not meet the inclusion criteria. Nine full-text articles were reviewed for eligibility, and finally, 8 were included for systematic review.

3.2. Study Characteristics. Altogether 8 articles were included in this review, out of which 7 were randomized controlled trials and one was a cross-sectional study (Hassan et al.). The studies covered a total of 2225 participants, out of which 1725 participants were treated with paromomycin. The study population ranged from 42 (Musa et al.) to 666 [1]. The studies were conducted in 7 different countries, one from Pakistan, one from East Africa (Sudan, Ethiopia, and Kenya), one from Bangladesh, one from Sudan, and four from India. This is illustrated in Figure 3. The year of publication of studies ranged from 1995 [18] to 2015 [19]. Visceral leishmaniasis was diagnosed in the studies using standard methods such as demonstration of parasites in bone marrow smear or rapid diagnostic test such as rk37. All studies had utilized microscopic examination of bone marrow or spleen aspirates to diagnose the patients, whereas, rk39 tests were employed by two studies (Jamil et al., Sinha et al.) to further confirm the diagnosis. None of the studies have clearly described the type of Leishmania species causing the disease among the study subjects. A detailed description of the characteristics of individual studies is shown in Table 1. 


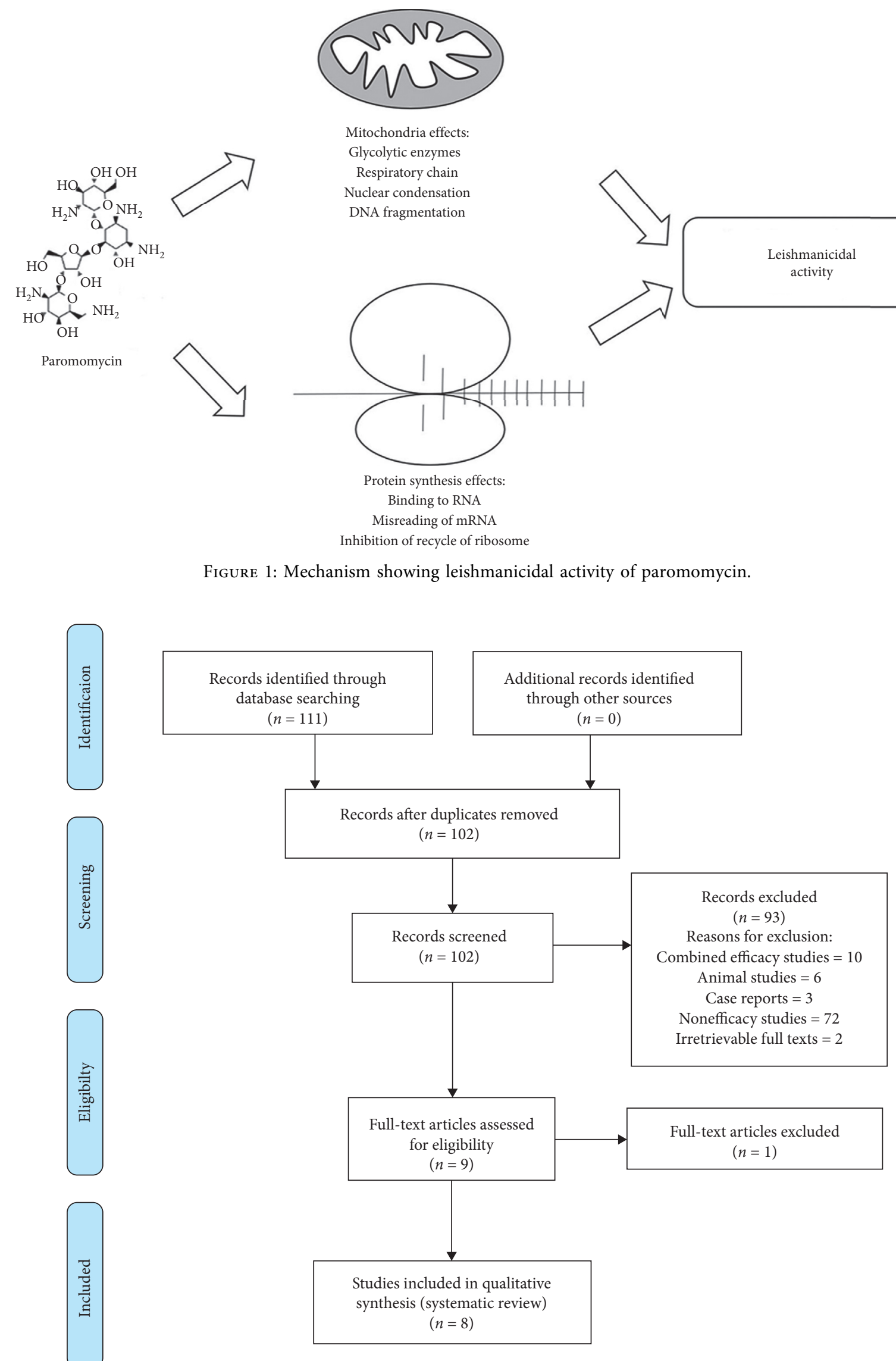

FIgURE 2: PRISMA flow diagram for study selection for the systematic review. 


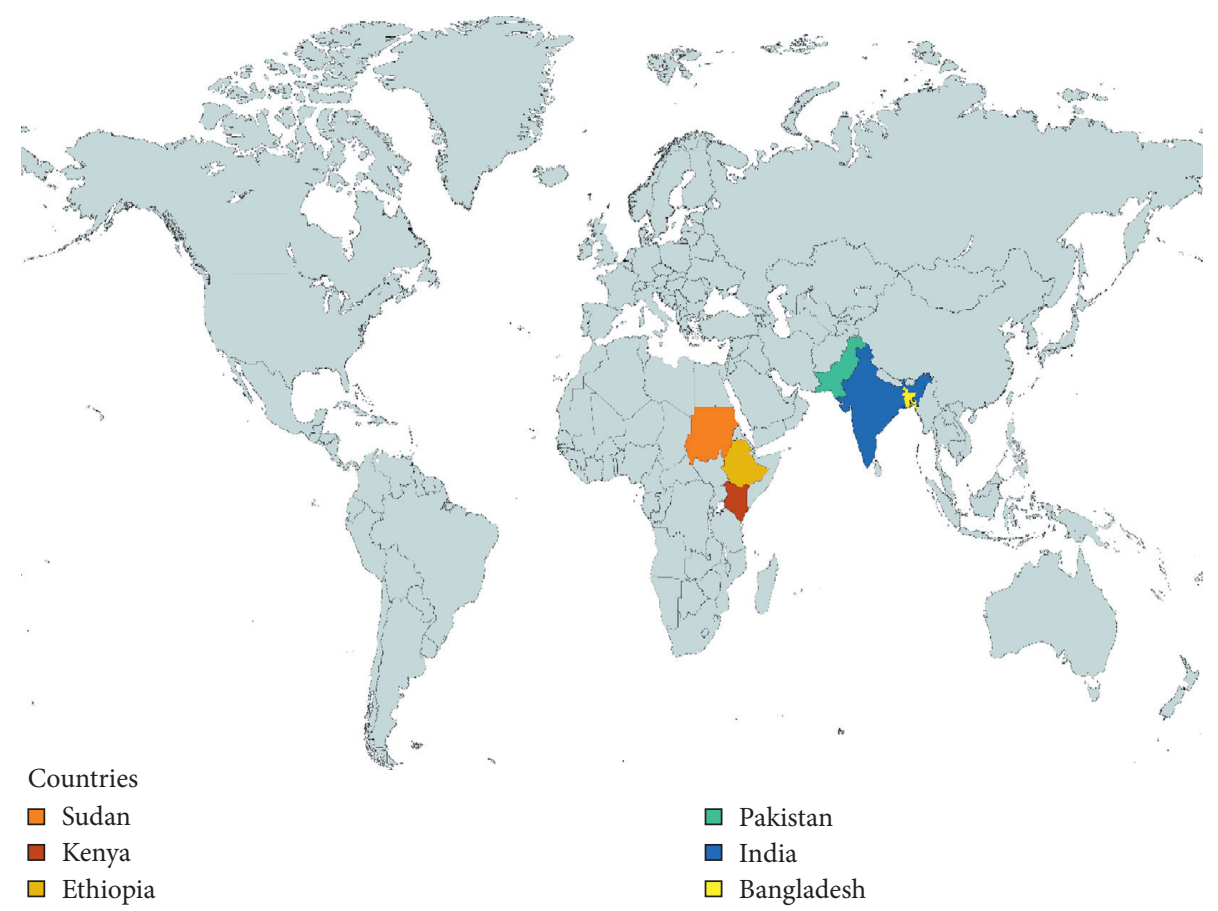

Figure 3: Countries included in the study.

TABLE 1: Characteristics of the included studies.

\begin{tabular}{|c|c|c|c|c|c|c|}
\hline Author & Year & Journal & Place/country & Study population & Age group & Study design \\
\hline $\begin{array}{l}\text { Hassan } \\
\text { et al. [18] }\end{array}$ & 1995 & $\begin{array}{l}\text { J Pak Med } \\
\text { Assoc }\end{array}$ & $\begin{array}{l}\text { Islamabad } \\
\text { Pakistan }\end{array}$ & $\mathrm{PM}=14, \mathrm{SSG}=36$ & $\begin{array}{c}1-5 \text { yrs }=40, \\
<1 \text { yrs }=5, \\
>5 \text { yrs }=5(\text { mean } \\
\text { age }=2.6 \text { yrs })\end{array}$ & Cross sectional \\
\hline $\begin{array}{l}\text { Hailu et al. } \\
{[16]}\end{array}$ & 2010 & $\begin{array}{l}\text { PLoS Negl } \\
\text { Trop Dis }\end{array}$ & $\begin{array}{l}\text { East Africa } \\
\text { (Sudan, } \\
\text { Ethiopia, and } \\
\text { Kenya) }\end{array}$ & $\begin{array}{c}P M=135, S S G=135 \\
S S G+P M=135\end{array}$ & $\begin{array}{l}4-60 \text { yrs }(\text { mean } \\
\text { age }=17.8)\end{array}$ & $\begin{array}{l}\text { Prospective, randomized, open } \\
\text { label, 3-arm trial carried out in five } \\
\text { centres of East Africa }\end{array}$ \\
\hline $\begin{array}{l}\text { Jamil et al. } \\
\text { [19] }\end{array}$ & 2015 & $\begin{array}{l}\text { PLoS Negl } \\
\text { Trop Dis }\end{array}$ & Bangladesh & 120 & $5-55$ yrs & $\begin{array}{c}\text { Phase IIIb open label, multicenter, } \\
\text { single-arm trial }\end{array}$ \\
\hline $\begin{array}{l}\text { Jha } \\
\text { et al. [20] }\end{array}$ & 1998 & BMJ & Bihar, India & $\begin{array}{c}\text { PM } 12 \mathrm{mg} \text { group }=30, \mathrm{PM} \\
16 \mathrm{mg} \text { group }=30, \mathrm{PM} \\
20 \mathrm{mg} \text { group }=30, \mathrm{SSG} \\
20 \mathrm{mg} \text { group }=30\end{array}$ & $6-55 \mathrm{yrs}$ & $\begin{array}{c}\text { Randomized unblinded controlled } \\
\text { trial } 4 \text {-armed study with } 30 \text { patient } \\
\text { each for aminosidine dosed } 12,16 \text {, } \\
\text { or } 20 \mathrm{mg} / \mathrm{kg} / \text { day for } 21 \text { days and } \\
\text { rest } 30 \text { patient for sodium } \\
\text { stibogluconate } 20 \mathrm{mg} / \mathrm{kg} / \text { day for } 30 \\
\text { days }\end{array}$ \\
\hline $\begin{array}{l}\text { Musa et al. } \\
{[21]}\end{array}$ & 2010 & $\begin{array}{l}\text { PLoS Negl } \\
\text { Trop Dis }\end{array}$ & Sudan & $\begin{aligned} \mathrm{PM} 20 \mathrm{mg} \text { group } & =21, \mathrm{PM} \\
15 \mathrm{mg} \text { group } & =21\end{aligned}$ & $4-60$ yrs & $\begin{array}{l}\text { Two-armed, randomized open } \\
\text { label dose finding phase II study at } \\
\text { a single site in Sudan, randomly } \\
\text { assigned to } 2 \text { groups }\end{array}$ \\
\hline $\begin{array}{l}\text { Sinha et al. } \\
{[22]}\end{array}$ & 2011 & $\begin{array}{l}\text { Journal of } \\
\text { Tropical } \\
\text { Medicine }\end{array}$ & Bihar, India & 494 & $2-55$ yrs & Phase IV open label trial \\
\hline $\begin{array}{l}\text { Sundar } \\
\text { et al. [1] }\end{array}$ & 2007 & $\begin{array}{l}\text { N. Engl } \\
\text { J. Med. }\end{array}$ & Bihar, India & $\mathrm{PM}=501, \mathrm{AmB}=165$ & $5-55$ yrs & $\begin{array}{c}\text { Open label, prospective, } \\
\text { randomized trial comparing } \\
\text { paromomycin with amphotericin B } \\
(3: 1 \text { block })\end{array}$ \\
\hline $\begin{array}{l}\text { Sundar } \\
\text { et al. [23] }\end{array}$ & 2009 & $\begin{array}{l}\text { Clin Infect } \\
\text { Dis }\end{array}$ & Bihar, India & $\begin{array}{l}\text { PM } 11 \mathrm{mg} \text { for } 14 \text { days }=217 \\
\text { PM } 11 \mathrm{mg} \text { for } 21 \text { days }=112\end{array}$ & $5-55$ yrs & $\begin{array}{l}\text { Randomized, open label study } \\
\text { intended to assess the efficacy and } \\
\text { safety of } 2 \text { regimens of } \\
\text { paromomycin administered } \\
\text { intramuscularly }\end{array}$ \\
\hline
\end{tabular}


3.3. Comparison of Treatment. The study conducted by Hassan et al. used $15 \mathrm{mg} / \mathrm{kg} /$ day im paromomycin for 4 weeks. Hailu et al. used $15 \mathrm{mg} / \mathrm{kg} /$ day im for 21 days. Jamil et al., Sinha et al., and Sundar et al. [1] used paromomycin dosed of $11 \mathrm{mg} / \mathrm{kg} / \mathrm{day}$ im for 21 days. The study conducted by Jha et al. used $12 \mathrm{mg}, 16 \mathrm{mg}$, and $20 \mathrm{mg}$ per $\mathrm{kg}$ body weight for 21 consecutive days. Similarly, the study by Sundar et al. [1] used $11 \mathrm{mg} / \mathrm{kg} /$ day for 14 days in one group and the same dose for 21 days in another group.

3.4. Comparison of Outcomes. The outcomes of the studies were the efficacy and safety. Efficacy was evaluated by initial clinical response which was defined as resolution of fever and reduction of splenomegaly at end of treatment. Final clinical response was defined as the absence of new clinical signs and symptoms of VL 6 months after end of treatment or absence of Leishmania parasites in the tissue aspirates at the end of 6 months. Safety issues were evaluated by the adverse events which occurred over the period of observation. Nonserious Adverse Events (AEs) were classified according to MedDRA, version 10, and defined as treatment emergent (TEAE) if onset was between the first day of treatment and 30 days after treatment. Severe or lifethreatening AEs are grade 3 or 4 adverse events according to Cancer Therapy Evaluation Program-Common Terminology Criteria for Adverse Events (CTEP-CTCAE) definition.

3.5. Efficacy/Cure. The efficacy of injectable paromomycin was variable depending upon the dose and duration of treatment. The initial efficacy was $100 \%$ in the study conducted by Hassan et al. using $15 \mathrm{mg} / \mathrm{kg} /$ day im paromomycin for 4 weeks and $67.4 \%$ in the study of Hailu et al. using $15 \mathrm{mg} / \mathrm{kg} /$ day im paromomycin for 21 days. In rest of the studies, the initial clinical response ranged from $85.7 \%$ in the study of Musa et al. conducted using $20 \mathrm{mg} / \mathrm{kg} /$ day for 21 days group to $98.6 \%$ in the study of Sundar et al.[1] conducted using paromomycin dosed $11 \mathrm{mg} / \mathrm{kg} /$ day for 21 days.

The final efficacy was highest of $97 \%$ in the study conducted by Jha et al. in the group of paromomycin dosed $20 \mathrm{mg} / \mathrm{kg} /$ day for 21 days and lowest of $63.8 \%$ in the East African study conducted by Hailu et al. using $15 \mathrm{mg} / \mathrm{kg} /$ day im paromomycin for 21 days. In the study of Hassan et al., the efficacy at the end of six months was not evaluated, but there were no relapses in follow-up to 1 year. A detailed description of the dose- and duration-based initial and final efficacy is shown in Table 2.

\subsection{Safety Issues on Paromomycin}

3.6.1. Adverse Events during Treatment with Paromomycin. All the studies in this review had collected data on Adverse Events (AEs) during treatment with paromomycin. Seven of the eight studies reported at least one adverse event among their participants. The total number of Treatment Emergent Adverse Events (TEAEs) among the studies ranges from 3 to 561. Four studies had reported severe or life-threatening AEs which have affected 63 subjects in total. Six of the studies in this review had reported subjects being discontinued from their study due to TEAEs. Furthermore, four studies had reported 40 Severe Adverse Events (SAEs) in total. A total of 6 deaths of subjects during study duration had been reported by four studies. Deaths in three studies had been reported as unrelated to the study drug $[1,19]$. Table 3 illustrates the number of patients who had different types of AEs during the treatment with paromomycin.

3.6.2. Classification of Nonserious AEs Reported during the Study. Paromomycin was well-tolerated, and the majority of the nonserious AEs reported by the studies were from the investigations. Increase in levels of alanine aminotransferase, aspartate aminotransferase, and blood alkaline phosphatase was commonly reported investigations. General disorders and administration site conditions are the second most common nonserious AEs. Injection site pain was the most frequent $\mathrm{AE}$ among general disorders and administration site conditions. Other nonserious AEs, which had been considered related to the paromomycin, are illustrated in Table 4.

\section{Discussion}

The objective of this systematic review was to look for the efficacy of injectable paromomycin for the treatment of visceral leishmaniasis and review its safety factors. The efficacy was studied by looking at the outcome at the end of treatment and cure rates at the end of six months of treatment. Safety aspects were reviewed by looking at the adverse events that happened during the treatment.

In the Indian population, the study conducted by Jha et al. showed a cure rate of $97 \%$ with paromomycin (PM) dosed $20 \mathrm{mg} / \mathrm{kg} /$ day for 21 days but only $77 \%$ cure rate with PM dosed $12 \mathrm{mg} / \mathrm{kg} /$ day for 21 consecutive days. However, the recent trials conducted by Sundar et al. and Sinha et al. showed a cure rate of more than $90 \%$ with PM dose of $11 \mathrm{mg} /$ $\mathrm{kg} /$ day for 21 days. In the only head-to-head trial of AmB deoxycholate and paromomycin conducted by Sundar et al., the authors concluded that the PM was noninferior in achieving definitive cure based on noninferiority testing with a noninferiority margin of 0.1 . The percentage difference in achieving definitive cure between the two regimens (4.2\%) and the upper bound of the $97.5 \%$ CI for this result (6.9\%) did not exceed the margin of noninferiority. In both groups, mortality rates were less than one percent $[1,22,23]$. Also, the trial conducted in Bangladesh showed an efficacy of $94.2 \%$ with the same dose and duration. Similarly, the study of Pakistan showed excellent efficacy of PM for the treatment of VL in children.

In the multicenter study conducted in East Africa (Sudan, Kenya, and Ethiopia) in the year 2010, it showed that the overall cure with PM (63.8\%) was significantly inferior to that with SSG (92.2\%) (difference of $28.5 \%, 95 \%$ CI: $18.8 \%$ to $38.8 \%, p<0.001)$ [16]. The efficacy of PM varied among centres and was significantly lower in Sudan $(14.3 \%$ and $46.7 \%)$ than in Kenya (80.0\%) and Ethiopia $(75.0 \%$ and $96.6 \%)$. This concludes that the efficacy of PM at $15 \mathrm{mg} / \mathrm{kg} /$ 
TABle 2: Efficacy of injectable paromomycin.

\begin{tabular}{|c|c|c|c|c|}
\hline Author & Year & Dose and duration & Initial efficacy (at the end of treatment) & Final efficacy (at the end of 6 months) \\
\hline $\begin{array}{l}\text { Hassan } \\
\text { et al. [18] }\end{array}$ & 1995 & $15 \mathrm{mg} / \mathrm{kg}$ im daily for 4 wks. & $14 / 14(100 \%)$ & $\begin{array}{l}\text { Not assessed; however, there were no } \\
\text { relapses in 1-year follow-up. }\end{array}$ \\
\hline $\begin{array}{l}\text { Hailu } \\
\text { et al. [16] }\end{array}$ & 2010 & $\begin{array}{l}15 \mathrm{mg} / \mathrm{kb} \text { body wt. im for } 21 \\
\text { days }\end{array}$ & $\begin{array}{l}\text { 67.4\% }(\text { Um el Kher, Sudan }=33.3 \%, \text { Kassab, } \\
\text { Sudan }=60 \%, \text { Kenya }=86.7 \%, \text { Gondar, } \\
\text { Ethiopia }=66.7 \%, \text { Arba Minch, } \\
\text { Ethiopia }=96.7 \%)(p \text { value }<0.001)\end{array}$ & $\begin{array}{c}63.8 \%(\text { Um el Kher, Sudan }=14.3 \%, \text { Kassab, } \\
\text { Sudan }=46.7 \%, \text { Kenya }=80 \%, \text { Gondar, } \\
\text { Ethiopia }=75 \%, \text { Arba Minch, } \\
\text { Ethiopia }=96.6 \%)(p \text { value }<0.001)\end{array}$ \\
\hline $\begin{array}{l}\text { Jamil } \\
\text { et al. [19] }\end{array}$ & 2015 & $\begin{array}{l}11 \mathrm{mg} / \mathrm{kg} \mathrm{BW} \text { im once daily } \\
\text { for } 21 \text { days }\end{array}$ & $98.3 \%$ & $94.2 \%$ \\
\hline $\begin{array}{l}\text { Jha et al. } \\
\text { [20] }\end{array}$ & 1998 & $\begin{array}{c}12,16 \text {, or } 20 \mathrm{mg} / \mathrm{kg} / \text { day for } \\
21 \text { days }\end{array}$ & $\begin{array}{l}12 \mathrm{mg} / \mathrm{kg} / \text { day group }=90 \%, 16 \mathrm{mg} / \mathrm{kg} / \text { day } \\
\text { group }=93.3 \%, 20 \mathrm{mg} / \mathrm{kg} / \text { day group }=90 \%\end{array}$ & $\begin{array}{c}12 \mathrm{mg} / \mathrm{kg} / \mathrm{day}=77 \%(n=23), 16 \mathrm{mg} / \mathrm{kg} / \\
\text { day }=93 \%(n=28), 20 \mathrm{mg} / \mathrm{kg} / \text { day }=97 \% \\
(n=29)\end{array}$ \\
\hline $\begin{array}{l}\text { Musa } \\
\text { et al. [21] }\end{array}$ & 2010 & $\begin{array}{l}20 \mathrm{mg} / \mathrm{kg} / \text { day for } 21 \text { days, } \\
15 \mathrm{mg} / \mathrm{kg} / \text { day for } 28 \text { days }\end{array}$ & $\begin{array}{l}20 \mathrm{mg} / \mathrm{kg} / \text { day group }=85.7 \%(95 \% \mathrm{CI}) \\
15 \mathrm{mg} / \mathrm{kg} / \text { day group }=90.5 \%(95 \% \mathrm{CI})\end{array}$ & $\begin{array}{c}20 \mathrm{mg} / \mathrm{kg} / \text { day group }=80 \%(95 \% \mathrm{CI}) \\
15 \mathrm{mg} / \mathrm{kg} / \text { day group }=81 \%(95 \% \mathrm{CI})\end{array}$ \\
\hline $\begin{array}{l}\text { Sinha } \\
\text { et al. [22] }\end{array}$ & 2011 & $11 \mathrm{mg} / \mathrm{kg} /$ day for 21 days & $99.6 \%(95 \% \mathrm{CI})$ & $94.2 \%(95 \% \mathrm{CI})$ \\
\hline $\begin{array}{l}\text { Sundar } \\
\text { et al. [1] }\end{array}$ & 2007 & $11 \mathrm{mg} / \mathrm{kg} /$ day for 21 days & $98.6 \%$ & $94.6 \%$ \\
\hline $\begin{array}{l}\text { Sundar } \\
\text { et al. [23] }\end{array}$ & 2009 & $\begin{array}{c}\text { Group } \mathrm{A}=11 \mathrm{mg} / \mathrm{kg} / \text { day for } \\
14 \text { days }(n=217) ; \text { group } \\
\mathrm{B}=11 \mathrm{mg} / \mathrm{kg} / \text { day for } 21 \text { days } \\
(n=112)\end{array}$ & Group $A=91.2 \%$, group $B=96.4 \%$ & Group $A=82 \%$, group $B=92 \%$ \\
\hline
\end{tabular}

Table 3: Number of patients developing AEs during treatment.

\begin{tabular}{|c|c|c|c|c|c|c|c|c|c|c|c|}
\hline Authors & Year & Journal & $\begin{array}{c}\text { Number } \\
\text { of } \\
\text { subjects }\end{array}$ & $\begin{array}{l}\text { Number } \\
\text { of deaths }\end{array}$ & $\begin{array}{l}\text { Patient } \\
\text { with at } \\
\text { least one } \\
\text { adverse } \\
\text { effect at } \\
\text { any time }\end{array}$ & $\begin{array}{l}\text { Patients } \\
\text { with } \\
\text { treatment- } \\
\text { related AE }\end{array}$ & $\begin{array}{l}\text { Patient with } \\
\text { severe or } \\
\text { life- } \\
\text { threatening } \\
\text { AE }\end{array}$ & $\begin{array}{l}\text { Discontinued } \\
\text { from study } \\
\text { due to } \mathrm{ADR}\end{array}$ & $\begin{array}{l}\text { Number } \\
\text { of SAEs }\end{array}$ & $\begin{array}{c}\text { No. of } \\
\text { patients } \\
\text { with } \\
\text { TEAEs }\end{array}$ & $\begin{array}{c}\text { Total } \\
\text { number } \\
\text { of } \\
\text { TEAEs }\end{array}$ \\
\hline $\begin{array}{l}\text { Hassan } \\
\text { et al. } \\
{[18]}\end{array}$ & 1995 & $\begin{array}{c}\text { J Pak Med } \\
\text { Assoc }\end{array}$ & 50 & 0 & 0 & 0 & 0 & 0 & 0 & 0 & 0 \\
\hline $\begin{array}{l}\text { Hailu } \\
\text { et al. } \\
{[16]}\end{array}$ & 2010 & PLoS NTD & 135 & 2 & 77 & 75 & 12 & 2 & 5 & 65 & 112 \\
\hline $\begin{array}{l}\text { Jamil } \\
\text { et al. } \\
{[19]}\end{array}$ & 2015 & PLoS NTD & 119 & 1 & 34 & 31 & 2 & 1 & 4 & 32 & 47 \\
\hline $\begin{array}{l}\text { Jha et al. } \\
{[20]}\end{array}$ & 1998 & $\mathrm{BMJ}$ & 90 & 0 & 3 & 3 & 0 & 1 & 0 & 3 & 3 \\
\hline $\begin{array}{l}\text { Musa } \\
\text { et al. } \\
{[21]}\end{array}$ & 2010 & PLoS NTD & 42 & 0 & N/A & N/A & 0 & 0 & 0 & N/A & 48 \\
\hline $\begin{array}{l}\text { Sinha } \\
\text { et al. } \\
{[22]}\end{array}$ & 2011 & $\begin{array}{c}\text { Journal of } \\
\text { Tropical } \\
\text { Medicine }\end{array}$ & 494 & 2 & 379 & 320 & 35 & 5 & 13 & 379 & 561 \\
\hline $\begin{array}{l}\text { Sundar } \\
\text { et al. [1] }\end{array}$ & 2007 & NEJM & 501 & 2 & 299 & 298 & 14 & 5 & 18 & 299 & 353 \\
\hline $\begin{array}{l}\text { Sundar } \\
\text { et al. } \\
{[23]}\end{array}$ & 2009 & $\begin{array}{l}\text { Clinical } \\
\text { Infectious } \\
\text { Diseases }\end{array}$ & 329 & 0 & N/A & N/A & N/A & 4 & N/A & N/A & 283 \\
\hline
\end{tabular}

day for 21 days was inadequate, particularly in Sudan. In the same year, the trial conducted by Musa et al. in Sudan with $20 \mathrm{mg} / \mathrm{kg} /$ day for 21 days and $15 \mathrm{mg} / \mathrm{kg} /$ day PM for 28 days showed cure rates of $80 \%$ and $81 \%$, respectively (95\% CI). The cure rates of VL with PM were still lower than those with
SSG. As the parasite type whether L. donovani or L. infantum was not isolated in the study, we could not speculate the correlation between the Leishmania species and low efficacy of the drug in African population. However, the potential causes for the low efficacy in Africa could be host-related 


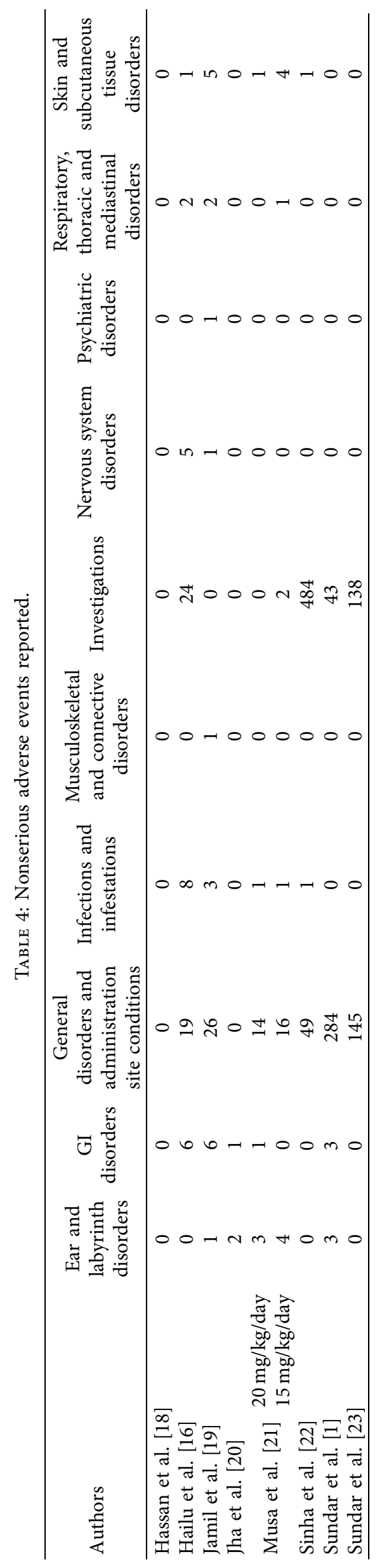


factors such as genetic or immunological variability or parasite-related factors such as innate drug resistance and parasite virulence differences. A study conducted by Verrest et al. concluded that differences in paromomycin pharmacokinetics do not explain the geographical variability in efficacy of paromomycin monotherapy among Eastern African and Indian VL patients [24]. So, we do not recommend $\mathrm{PM}$ as a first-line drug in Africa instead the drug can be reserved for cases resistant to SSG or places where AmB cannot be afforded. Also, further studies in potential parasite factors and host factors are required to find out the likely causes.

Furthermore, there are no efficacy studies of PM for the treatment of visceral leishmaniasis from the endemic areas of South America till date. Therefore, there is an immediate need for efficacy and safety studies in this region to support evidence-based kala-azar treatment.

Paromomycin is a relatively safe drug with very few serious adverse events and events of death. Even though paromomycin is an aminoglycoside, its well-known side effects such as ototoxicity and nephrotoxicity are reported in few patients of VL. Moreover, a large number of increases in liver enzymes reported by the studies are reversible, and only a few of those patients required discontinuation of therapy. The increase in liver enzymes is considered to be the result of the destruction of parasites in the liver. Parenteral aminoglycosides are rarely associated with the increase in liver enzymes in general [25]. Hearing impairment seen during or at the end of the treatment in the studies resolved with time, and no permanent changes were reported. Hence, periodic audiometric testing should be conducted for the patients receiving treatment with paromomycin. Proper management of general disorders such as pyrexia and nausea along with administration site conditions such as injection pain will increase the overall compliance of the patient to the treatment.

Our study has few limitations. Studies from various kala-azar endemic countries were lacking, so optimal dose of PM for treatment of VL worldwide could not be estimated. Also, we had two irretrievable full texts which could have affected the potential outcomes. Owing to the above limitations, the results of this review should be interpreted with caution.

\section{Conclusion}

Paromomycin can be a drug of choice for treatment of visceral leishmaniasis in the Indian subcontinent and in resource-limited settings where expensive drugs such as L-AmB are not available readily. The optimal dose of paromomycin for treatment of VL in the Indian subcontinent is $11 \mathrm{mg}$ per $\mathrm{kg}$ body weight for 21 days. However, in regions of Africa, paromomycin should be reserved for cases where the efficacy of other first-line antileishmanial drugs is limited. Further single and headto-head trials of paromomycin should be conducted in kala-azar endemic areas to know the exact efficacy and dose of antileishmanial drugs and to eliminate kala-azar as a global health problem.

\section{Abbreviations}

VL:

PM:

NTDs:

DALYs:

WHO:

im:

BW:

SSG:

AmB:

L. AmB:

AE:

TEAE:

SAE:

ADR:

CTEP-

CTCAE:

N/A:

Visceral leishmaniasis

Paromomycin

Neglected tropical diseases

Disability adjusted life years

World Health Organization

Intramuscular

Body weight

Sodium stibogluconate

Amphotericin B

Liposomal amphotericin B

Adverse Event

Treatment Emergent Adverse Event

Serious Adverse Event

Adverse drug reaction

Cancer Therapy Evaluation Program-

Common Terminology Criteria for Adverse

Events

Not available.

\section{Data Availability}

No data were used to support the findings of this study.

\section{Conflicts of Interest}

The authors declare no conflicts of interest.

\section{References}

[1] S. Sundar, T. K. Jha, C. P. Thakur, P. K. Sinha, and S. K. Bhattacharya, "Injectable paromomycin for Visceral leishmaniasis in India," New England Journal of Medicine, vol. 356, no. 25, pp. 2571-2581, 2007.

[2] J. Alvar, S. Yactayo, and C. Bern, "Leishmaniasis and poverty," Trends in Parasitology, vol. 22, no. 12, pp. 552-557, 2006.

[3] G. Yamey, "The world's most neglected diseases," British Medical Journal, vol. 325, no. 7357, pp. 176-177, 2002.

[4] N. J. Kassebaum and M. Arora, "Global, regional, and national disability-adjusted life-years (DALYs) for 359 diseases and injuries and healthy life expectancy (HALE) for 195 countries and territories, 1990-2017: a systematic analysis for the global burden of disease study 2017," Lancet, vol. 392, no. 10159, pp. 1859-1922, 2018.

[5] N. J. Kassebaum, M. Arora, R. M. Barber et al., "Global, regional, and national disability-adjusted life-years (DALYs) for 315 diseases and injuries and healthy life expectancy (HALE), 1990-2015: a systematic analysis for the global burden of disease study 2015," The Lancet, vol. 388, no. 10053, pp. 1603-1658, 2016.

[6] T. Burki, "East African countries struggle with visceral leishmaniasis," The Lancet, vol. 374, no. 9687, pp. 371-372, 2009.

[7] “Leishmaniasis," 2020, https://www.who.int/news-room/factsheets/detail/leishmaniasis.

[8] “Leishmaniasis (Internet)," 2021, https://www.who.int/data/ gho/data/themes/topics/topic-details/GHO/leishmaniasis.

[9] Pan American Health Organization, Leishmaniases. Epidemiological Report of the Americas, December 2020, Pan American Health Organization, Washington, D.C., USA, 2020. 
[10] S. Rijal, F. Chappuis, R. Singh, M. Boelaert, L. Loutan, and S. Koirala, "Sodium stibogluconate cardiotoxicity and safety of generics," Transactions of the Royal Society of Tropical Medicine and Hygiene, vol. 97, no. 5, pp. 597-598, 2003.

[11] C. P. Thakur, G. P. Sinha, A. K. Pandey et al., "Do the diminishing efficacy and increasing toxicity of sodium stibogluconate in the treatment of visceral leishmaniasis in Bihar, India, justify its continued use as a first-line drug? an observational study of 80 cases," Annals of Tropical Medicine \& Parasitology, vol. 92, no. 5, pp. 561-569, 1998.

[12] S. L. Croft, S. Sundar, and A. H. Fairlamb, "Drug resistance in leishmaniasis," Clinical Microbiology Reviews, vol. 19, no. 1, pp. 111-126, 2006.

[13] E. Rosenthal and P. Marty, "Recent understanding in the treatment of visceral leishmaniasis," Journal of Postgraduate Medicine, vol. 49, no. 1, pp. 61-68, 2003.

[14] S. Sundar and M. Rai, "Advances in the treatment of leishmaniasis," Current Opinion in Infectious Diseases, vol. 15, no. 6, pp. 593-598, 2002.

[15] S. Sundar, T. K. Jha, C. P. Thakur et al., "Oral miltefosine for Indian visceral leishmaniasis," New England Journal of Medicine, vol. 347, no. 22, pp. 1739-1746, 2002.

[16] A. Hailu, A. Musa, M. Wasunna et al., "Geographical variation in the response of visceral leishmaniasis to paromomycin in East Africa: a multicentre, open-label, randomized trial," PLoS Neglected Tropical Diseases, vol. 4, no. 10, p. e709, 2010.

[17] A. P. S. Matos, A. L. Viçosa, M. I. Ré, E. Ricci-Júnior, and C. Holandino, "A review of current treatments strategies based on paromomycin for leishmaniasis," Journal of Drug Delivery Science and Technology, vol. 57, Article ID 101664, 2020.

[18] M. Hassan, D. B. Baat, and K. Hassan, "A new breakthrough in treatment of visceral leishmaniasis in children," JPMA. The Journal of the Pakistan Medical Association, vol. 45, no. 6, pp. 155-157, 1995.

[19] K. M. Jamil, R. Haque, R. Rahman et al., "Effectiveness study of paromomycin IM injection (PMIM) for the treatment of visceral leishmaniasis (VL) in Bangladesh," PLoS Neglected Tropical Diseases, vol. 9, no. 10, Article ID e0004118, 2015.

[20] T. K. Jha, P. Olliaro, C. P. N. Thakur et al., "Randomised controlled trial of aminosidine (paromomycin) $\mathrm{v}$ sodium stibogluconate for treating visceral leishmaniasis in North Bihar, India commentary: some good news for treatment of visceral leishmaniasis in Bihar," British Medical Journal, vol. 316, no. 7139, pp. 1200-1205, 1998.

[21] A. M. Musa, B. Younis, A. Fadlalla et al., "Paromomycin for the treatment of visceral leishmaniasis in Sudan: a randomized, open-label, dose-finding study," PLoS Neglected Tropical Diseases, vol. 4, no. 10, p. e855, 2010.

[22] P. K. Sinha, T. Jha, C. P. Thakur et al., "Phase 4 pharmacovigilance trial of paromomycin injection for the treatment of visceral leishmaniasis in India," Journal of Tropical Medicine, vol. 2011, Article ID 645203, 7 pages, 2011.

[23] S. Sundar, N. Agrawal, R. Arora, D. Agarwal, M. Rai, and J. Chakravarty, "Short-course paromomycin treatment of visceral leishmaniasis in India: 14-day vs 21-day treatment," Clinical Infectious Diseases, vol. 49, no. 6, pp. 914-918, 2009.

[24] L. Verrest, M. Wasunna, G. Kokwaro et al., "Geographical variability in paromomycin pharmacokinetics does not explain efficacy differences between eastern african and Indian visceral leishmaniasis patients," Clinical Pharmacokinetics, vol. 47, 2021.
[25] M. C. Aminoglycosides, Goodman \& Gilman's: The Pharmacological Basis of Therapeutics, 13e, McGraw-Hill Education, New York, NY, USA, 2017. 